\title{
KEPEMIMPINAN PENDIDIKAN DAN PEMBELAJARAN DI LINGKUNGAN SEKOLAH
}

\author{
Aris Munandar \\ Sekolah Dasar Negeri (SDN) 02 Kota Bima \\ Email: arismunandarndar643@gmail.com
}

\begin{abstract}
Abstrak
Penulisan artikel tentang kepemimpinan adalah dengan menggunakan peulisan lewat kaiian pustaka dan beberapa teori dari sumber lain tentang kepemimpinan baik kepemimpinan pendidikan maupun kepemimpinan dalam pembelajaran. Kepemimpinan adalah proses mempengaruhi atau memberi contoh oleh pemimpin kepada pengikutnya dalam upaya mencapai tujuan organisasi. kepemimpinan adalah suatu proses yang dilakukan manajer perusahaan untuk mengarahkan (directing) dan mempengaruhi (influencing) para bawahannya dalam kegiatan yang berhubungan dengan tugas (task-related aktivities), agar para bawahannya mau mengerahkan seluruh kemampuannya, baik sebagai pribadi maupun sebagai anggota tim, untuk mencapai tujuan yang telah ditetapkan perusahaan. Pemimpin yang berhasil hendaknya memiliki beberapa kriteria yang tergantung pada sudut pandang atau pendekatan yang digunakan, apakah itu kepribadiannya, keterampilan, bakat, sifatsifatnya, atau kewenangannya yang dimiliki yang mana nantinya sangat berpengaruh terhadap teori maupun gaya kepemimpinan yang akan diterapkan.
\end{abstract}

Kata Kunci: Kepemimpinan, Pendidikan, Pembelajaran.

\section{PENDAHULUAN}

epemimpinan adalah proses mempengaruhi atau memberi contoh
oleh pemimpin kepada pengikutnya dalam upaya mencapai tujuan
organisasi. Dalam setiap kelompok, group atau organisasi, kepemimpinan merupakan salah satu factor yang penting. Kepemimpinan yang ada akan mempengaruhi kelompok di dalam mencapai tujuan. Cara seseorang memimpin dapat membawa kelompok atau organisasi tersebut ke arah keberhasilan atau ketidak berhasilan dalam mencapai tujuan yang telah ditetapkan. Manusia adalah makhluk social yang tidak dapat hidup sendiri. Dalam hidup, manusia selalau berinteraksi dengan sesame serta dengan 
lingkungan. Manusia hidup berkelompok baik dalam kelompok besar maupun dalam kelompok kecil. Hidup dalam kelompok tentulah tidak mudah. Untuk menciptakan kondisi kehidupan yang harmonis anggota kelompok haruslah saling menghormati dan menghargai. Keteraturan hidup perlu selalu dijaga. Hidup yang teratur adalah impian setiap insan. Menciptakan dan menjaga kehidupan yang harmonis adalah tugas manusia.

Manusia adalah makhluk Tuhan yang paling tinggi disbanding makhluk Tuhan lainnya. Manusia di anugerahi kemampuan untuk berpikir, kemampuan untuk memilah dan memilih mana yang baik \& mana yang buruk. Dengan kelebihan itulah manusia seharusnya mampu mengelola lingkungan dengan baik. Tidak hanya lingkungan yang perlu dikelola dengan baik, kehidupan social manusiapun perlu dikelola dengan baik. Untuk itulah dibutuhkan sumber daya manusia yang berkualitas. Sumber daya yang berjiwa pemimpin, paling tidak untuk memimpin dirinya sendiri. Dengan berjiwa pemimpin manusia akan dapat mengelola diri, kelompok \& lingkungan dengan baik. Khususnya dalam penanggulangan masalah yang relatif pelik dan sulit. Disinilah dituntut kearifan seorang pemimpin dalam mengambil keputusan agar masalah dapat terselesaikan dengan baik.

Bicara tentang kepemimpinan bukan hanya pada tataran pemerintahan yang ada dimasing-masing negara seperti mulai dari presiden hingga ke kepala RT. Tapi pemimpin membicarakan persoalan yang ada dalam kehidupan kelompok misalanya dalam kehidupan bermasyarakat, kehidupan berkelompok, kehidupan berkeluarga, kehidupan ber rumah tangga. Dan bahkan dalam lembaga pendidikan itu sangat memerlukan kepeimimpinan atau pemimpin yang mengatur dan mengelolah. Kepemimpinan dalam pendidika adalah untuk mengelola pendidikan agar berjalan dengan maksimal sesuai dengan kurikulum yang berlaku. 


\section{Pengertian Kepemimpinan}

Definisi tentang kepemimpinan bervariasi sebanyak orang yang mencoba mendefinisikan konsep kepemimpinan. Definisi kepemimpinan secara luas adalah meliputi proses mempengaruhi dalam menentukan tujuan organisasi, memotivasi perilaku pengikut untuk mencapai tujuan, mempengaruhi untuk memperbaiki kelompok dan budayanya. Selain itu juga mempengaruhi interpretasi mengenai peristiwa-peristiwa para pengikutnya,pengorganisasian dan aktivitas-aktivitas untuk mencapai sasaran, memelihara hubungan kerja sama dan kerja kelompok, perolehan dukungan dan kerja sama dari orang-orang di luar kelompok atau organisasi.

Menurut solihin (2010), kepemimpinan adalah suatu proses yang dilakukan manajer perusahaan untuk mengarahkan (directing) dan mempengaruhi (influencing) para bawahannya dalam kegiatan yang berhubungan dengan tugas (task-related aktivities), agar para bawahannya mau mengerahkan seluruh kemampuannya, baik sebagai pribadi maupun sebagai anggota tim, untuk mencapai tujuan yang telah ditetapkan perusahaan. Hakekat kepemimpinan ialah bahwa atasan mempengaruhi perilaku orang lain didalam kerjanya dengan menggunakan kekuasaan. Kekuasaan adalah kemampuan seseorang agar yang bersangkutan mengerjakan apa yang dikehendaki. Kepemimpinan dipahami dalam dua pengertian yaitu sebagai kekuatan untuk menggerakkan dan mempengaruhi orang. Kepemimpina hanyalah sebuah alat, sarana atau proses untuk membujuk orang agar bersedia melakukan sesuatu secara suka rela/ suka cita.Kepemimpinan adalah proses mengarahkan dan mempengaruhi aktivitas-aktivitas yang ada hubungannya dengan pekerjaan para anggota kelompok. Dari pengertian di atas dapat kami simpulkan bahwa kepemimpinan adalah proses mempengaruhi, mengarahkan, atau memberi 
contoh kepada pengikutnya untuk mencapai tujuan organisasi yang diharapkan.

\section{Kepemimpinan Dalam Pendidikan}

Kepemimpinan pendidikan merupakan salah satu kunci sukses dalam pengelolaan pendidkan, terutama dalam menggerakan sumber daya manusia dalam pendidikan. Dapat difahami bahwa kepemimpinan pendidikan pada dasarnya merupakan penerapan kepemimpinan dalam dunia pendidikan. Secara luas dapat digambarkan bahwa kepemimpinan pendidikan merupakan usaha yang dilakukan pemimpin atau dalam lembaga atau organisasi pendidikan (sekolah atau perguruan tinggi. Halitu untuk menggerkan atau memberdayakan sumber daya manusia dan sumber daya selain manusia guna mencapai tujuan yang telah ditetapkan secara efektif dan efisien. Untuk memahami kepemimpinan pendidikan Wahab 2008132138) menjelaskan panjang lebar tentang kepemimpinan pendidikan sejak dari pengertian fungsi, tipe-tipe sampai dengan syarat-syarat kepemimpinan pendidikan. Menurut ia kepemimpinan pendidikan adalah suatu kualitas kegiatan-kegiatan dan integrasi didalam situasi pendidikan. Kepemimpinan pendidikan merupakan kemampuan untuk menggerakan pelaksanaan pendidikan, sehingga tujuan pendidikan yang telah ditetapkan dapat tercapai secara efektif dan efisien Mengenai fungsi kepemimpinan pendidikan Wahab menerangkan bahwa fungsi utama pemimpin pendidikan anatara lain:

1. Pemimpin membantu terciptanya suasana persaudaraan, kerja sama, dengan penuh rasa kebebasan.

2. Pemimpin membantu kelompok untuk mengorganisir diri yaitu ikut serta dalam memberikan rangsangan dan bantuan kepada kelompok dalam menentapakan dan menjelaskan tujuan. 
3. Pemimpin membantu kelompok dalam menetapkan prosedur kerja, yaitu membantu kelompok dalam menganalisis situasi untuk kemudian menetapkan prosedur mana yang paling praktis dan efektif.

4. Pemimpin bertanggung jawab dalam mengambil keputusan bersama dengan kelompok. Pemimpin memberi kesempatan kepada kelompok untuk belajar dari pengalaman. Pemimpin mempunyai tangung jawab untuk melatih kelompok menyadari proses dan isi pekerjaan yang dilakukan dan berani menilai hasilnya secara jujur dan obyektif.

5. Pemimpin bertanggung jawab dalam mengembangkan dan mempertahankan eksistensi organisasi.

Adapun mengenai tipe-tipe kepemimpinan pendidikan Wahab menyebutkan sebagaimana tipe-tipe kepemimpinan pada umumnya, yaitu: tipe otoriter, laiser faire, demokratis dan pseudo demokratis atau demokratis semu. Mengenai persyaratan, pemimpin pendidikan untuk memangku jabatan yang dapat melaksanakan tugas-tugasnya dan memainkan perannya sebagai pemimpin yang baik dan sukses, dituntut bebrapa persyaratan jasmani, rohani dan moralitas yang baik, bahkan persyaratan ekonomi sosial yang layak. Dalam hal ini Wahab hanya mengemukakan persayaratanpersyaratan kepribadian, yaitu: 1. Reandah hati dan sederhana; 2. Bersifat suka menolong; 3. Sehat dan memiliki kestabilan emos; 4. Percaya kepada diri sendiri; 5. Jujur, adil, dan dapat dipercaya; 6. Keahlian dalam jabatan. Kemudian disamping persyaratan-persyaratn diatas seorang pemimpin pendidikan juga harus memiliki keterampilan-keterampilan, antara lain: 1. Keterampilan dalam memimpin;2. Keterampilan dalam hubungan insani; 3. Keterampilan dalam proses kelompok, 4. Keterampilan dalam administrasi personil, dan; 5. Keterampilan dalam menilai (Samino, 2010).

\section{Kepemimpinan Dalam Pembelajaran}

Kepemimpinan pembelajaran adalah kepemimpinan yang menfokuskan atau menekanakan pada pemebelajaran. Komponenkomponen kepemimpinan pembelajaran meliputi kurikulum, proses belajar 
mengajar, asesmen, penilaian, pengembangan guru, layanan prima dalam pembelajaran, dan pembangunan kmunitas belajar disekolah.

1. Tujuan kepemimpinan pembelajara

Tujuan utama kepemimpinan pembelajaran adalah memberikan layanan prima kepada siswa dan siswa mampu mengembangkan

potensinya untuk menghadapi masa depan yang belum diketahui dan sarat dengan tantangan-tantangan yang sangat turbulen. Dengan kata lain, tujuan kepemimpinan pembelajaran adalah untuk memfasilitasi pembelajaran agar terjadi peningkatan prestasi belajar, kepuasan belajar, motivasi belajar, keingintahuan, kreativitas, inovasi, jiwa kewirausahaan, dan kesadaran untuk belajar sepanjang hayat karena ilmu pengetahuan dan teknologi serta seni berkembang dengan pesat.

2. Pentingnya Kepemimpinan Pembelajaran

Kepemimpinan pembelajaran sangat penting untuk diterapkan disekolah karena mampu: a) meningkatkan prestasi belajar siswa secara signifikan; b) mendorong dan mengarahkan warga sekolah untuk meningkatkan prestasi belajar siswa; c) memfokuskan kegiatan-kegiatan warga sekolah untuk menuju pencapaian visi, misi, dan tujuan sekolah; dan d) membangun komunitas belajar warga dan bahkan mampu menjadikan sekolahnya sebagai sekolah belajar (learning school). Sekolah belajar memiliki perilaku-perilaku sebagai berikut: memberdayakan warga sekolah seoptimal mungkin; memfasilitasi warga sekolah untuk belajar terus dan berulang-ulang; mendorong kemandirian setiap warga sekolahnya; memberi kewenangan dan tanggungjawab kepada warga sekolahnya; mendorong warga sekolah untuk akuntabel terhadap proses dan hasil kerjanya; mendorong teamwork yang (kompak, cerdas, dinamis, harmonis, dan lincah/cepat tanggap terhadap pelanggan 
utama yaitu siswa); mengajak warga sekolah untuk menjadikan sekolah berfokus pada layanan siswa; mengajak warga sekolah untuk siap dan akrab menghadapi perubahan, mengajak warga sekolah untuk berpikir sistem; mengajak warga sekolah untuk komitmen terhadap keunggulan mutu, dan mengajak warga sekolah untuk melakukan perbaikan secara terus-menerus (Wijanarko, 2019).

\section{SIMPULAN}

Kepemimpinan adalah kekuasaan untuk mempengaruhi seseorang, baik dalam mengerjakan sesuatu atau tidak mengerjakan sesuatu. Seseorang dikatakan sebagai pemimpin apabila dia mempunyai pengikut atau bawahan. Kata pemimpin, kepemimpinan serta kekuasaan memiliki keterikatan yang tak dapat dipisahkan. Karena untuk jadi pemimpin bukan hanya berdasarkan suka satu sama lainnya, tetapi banyak faktor. Pemimpin yang berhasil hendaknya memiliki beberapa kriteria yang tergantung pada sudut pandang atau pendekatan yang digunakan, apakah itu kepribadiannya, keterampilan, bakat, sifat-sifatnya, atau kewenangannya yang dimiliki yang mana nantinya sangat berpengaruh terhadap teori maupun gaya kepemimpinan yang akan diterapkan. Semakin tinggi kedudukan seorang pemimpin dalam organisasi maka semakin dituntut daripadanya kemampuan berfikir secara konsepsional dan makro. Semakin tinggi kedudukan seseorang dalam organisasi maka ia akan semakin generalist, sedangkan semakin rendah kedudukan seseorang dalam organisasi maka ia menjadi spesialist. Dan juga kepemimpinan dalam pedidikan merupakan usaha yang dilakukan oleh pemimpin untuk meyatukan dan menggerakan atau memberdayakan sumber daya manusia, kepemimpinan pembelajaran adalah kepemimpinan yang memfokuskan/ menekankan pada pembelajaran. 


\section{DAFTAR PUSTAKA}

Samino. 2010. Kepemimpinan Pendidikan. Surakarta: Fairuz Media.

Solihin, I. 2010. Pengantar Manajemen. Bandung: Erlangga.

http://blog.unnes.ac.id/sriwaeni/2015/11/11/artikel-kepemimpinan/.DIakses pada $\operatorname{tg} 26$ februari 2019.

https://liyacatur262.wordpress.com/tugas-internet-dan-desain-web/artikelkepemimpinan. Diakses pada tgl 26 Feb 2019.

http://www.vedcmalang.com/pppptkboemlg/index.php/menuutama/departe men-bangunan-30/1352-b-wijanarko diakses pada tgl 262019. 